\title{
Psychiatry at Glastonbury Festival
}

\author{
Anna Knight and Michael Hughes
}

Having viewed the Glastonbury Festtval for many years as local residents, it seemed time for us to venture inside and see how 100,000 people can converge onto a datry farm in rural Somerset for three days of music and assorted entertainments. We were interested in reactions to such intensely communal itving and also the organisational aspects of psychiatric services in this extreme version of community care.

The festtval is now in its 24th year and has attracted much publicity locally and nationally. Concerns have been ralsed that such a large number of people put undue pressure on the local medical and police services, and that undestrable, drug-dealing 'hippies' are attracted into the area. In the past there has been evidence of 'new age travellers' congregating in the area, but this time they seem to have been kept well away, and only those with $\$ 59$ entrance tickets allowed near. Officlally the entertainment started on Friday, 24 June 1994 lasting untll Sunday night, but people started arriving a few days beforehand, and drifted away afterwards equally sporadically.

There is a wide range of formalised and informal services providing medical and emotional support and treatment. The medical centre itself is sited at the farmhouse, where 60 doctors and nearly 400 other clinical staff provide 24 hour cover, mostly on a voluntary basis-nearly 2000 people used this provision over the weekend. Cover for the rest of the site was from two paramedic crews and voluntary services.

An on-call psychiatrist was avallable round the clock and community psychiatric nurses attached to the festival welfare tents scattered across the fields. The Samaritans had two well placed tents to cope with personal crises as relationships and individuals' sanity were stretched by the unfamiliar stresses encountered in the festival environment. Drugs were felt to be a major factor by voluntary workers, as revellers experimented, used unknown suppliers, and consumed to excess. Another common theme was people who had tried to escape from personal problems only to find them compounded.

One of us (AK) undertook a shift as the duty psychiatrist on the Monday. Although this was offictally at the end, the impression was that most people had not yet left. As I walked onto the site I was bombarded by smells-urine, decaying bonfires and fried food. There was an air of stilliness, contrasting with the sense of expectancy earlier. People, tramping through the litter, looked weary and jet-lagged. I was struck by the uniformity of those seeking to be 'alternattve'; ageless, sexless, classless and raceless in appearance and manner.

With a bleep and a bottle of diazepam I set off. The well provisioned pharmacy was being packed away, useful telephone numbers stripped from the wall, ambulances setting off back to their stations but my most pressing problem was the closure of the welfare services. These included a large barn decked out with old beds and sofas, cups of tea and reassuring faces, where those having frightening drug-related experlences can find security. Unfortunately the service was due to close on Monday at 6 p.m., so those languishing there during the afternoon were unable to have the luxury of time and decisions had to be made regarding their immediate future.

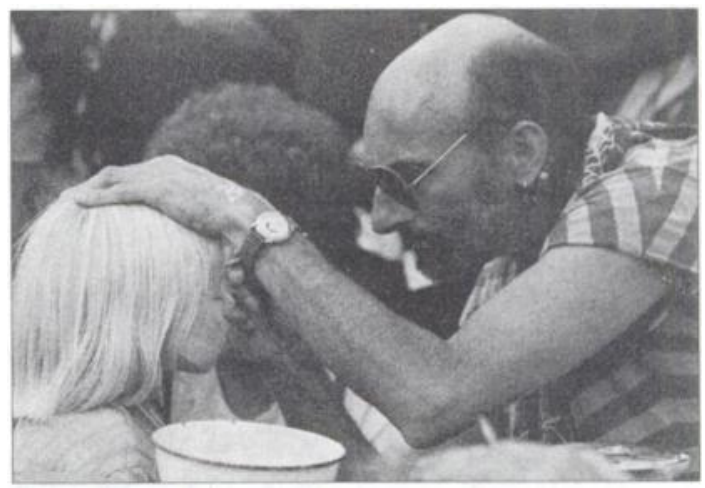

Face painting in the Green Field. 


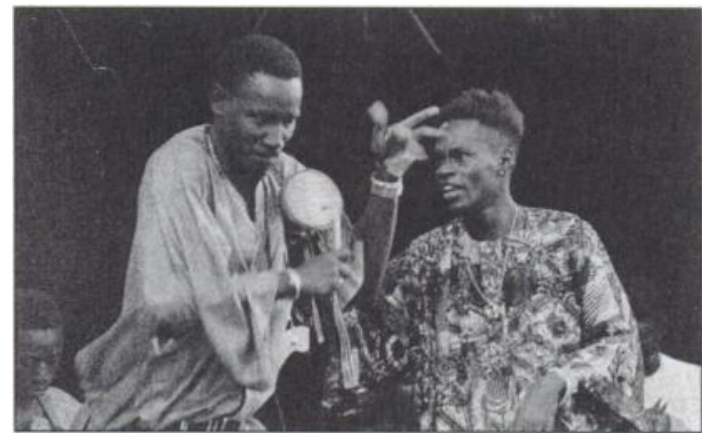

Senegalese Music from Baaba Maal adds an African flavour to the festival.

Jason from Glasgow, curled up in a blanket tearfully told me he daren't go out as "black men will cut off my willy". He had seen a psychiatrist in Glasgow once because "I'm paranoid three weeks out of four" but had not got help. It was unclear what drugs he had been using recently, but he admitted smoking cannabis heavily on Saturday night. By now his friends had disappeared, and time (36 hours) and diazapam had made Httle impression on his fear so admission to an acute psychiatric ward in Bath was arranged.

The next call was to a man having "some sort of fit". When we got there the paramedic team were monitoring and administering oxygen. The psychiatric view was of a panic attack but oral diazepam seemed to have little effect. Only when rolling up his sleeve to contemplate IV diazepam were the needle tracks spotted and the patient admitted to pretence as he had run out of supplies, and he had heard that the medical services would not be generous if he presented himself as a withdrawing addict.

Lucy was a teenager having a "wonderful time" and had not slept for 36 hours by using various unknown drugs. She had a coach ticket back to Blackpool but it seemed hard to imagine her sitting still throughout the journey. She realised this might be a problem and requested medication (i.e. diazepam) which she treated with much suspicion. I was struck by the paradox that many drug users accept unknown drugs from strangers but are alarmed at accepting legal drugs from a doctor.
A young charity worker who had eaten a 'hash cake' (cannabis) on Saturday night was still perplexed and disorientated. Fortunately he had supportive friends who, with diazepam. were able to drtve him home.

The psychiatrists working Friday to Monday saw 37 people of whom 25 were male and all aged 16-26 years; 13 were problems directly relating to illegal drug consumption. There were eight requests for replacement methadone but no controlled drugs were kept on site.

Paranoid symptoms were common, on two occasions relating to 'travellers'. Many of those with paranold ideation sought comfort and security by physical proximity to the police compound-a polgnant regression. The expressed fears may also relate to the suspictous and sinister atmosphere in parts of the site. During the festival itself there were two admissions, one under section 2 of the Mental Health Act, for a paranoid psychotic illness. The two week period after yielded four admissions in the Somerset area that appeared related to the event, in causation or because people suffering a known mental health problem relapsed before they reached home.

\section{Concluding remarts}

Attendance at the festival was a worthwhile experience, allowing an understanding of the necessary flexdbility in providing psychiatric cover for such an event. The acute drugrelated states offered a different insight from a hospital or casualty department setting. The non-hierarchical relationships between the medical, para-medical and voluntary agency staff allowed efficient and appropriate care to be provided across the site.

Anna Knight, Senior Registrar, Phoenix House, Prlory Park Hospttal, Glastonbury Road, Wells, Somerset; and Michael Hughes Senior House Officer, Tone Vale Hospital, Dene Road, Norton Fitzuarren, Taunton, Somerset TA4 1DB 